\title{
歯性上顎洞炎における線毛上皮の走查電顕的観察
}

\author{
吉田 徹・塩田 覚・船本長一朗・高沢一良 \\ 中村 哲

\section{Scanning electron microscopic observation of the ciliated epithelia in the odontogenic maxillary sinusitis}

\author{
Toru Yoshida - Satoru Shiota - Choichiro Funamoto \\ Kazuyoshi TAKazawa - Satoshi NaKamura
}

\begin{abstract}
It has been said that chronicity of odontogenic maxillary sinusitis induces changes in the maxillary sinus mucosa due to causative organism and develops attributively to retention caused by decreased excretion of inflammatory products. It has been considered that not only the pathogenicity of the microorganism but also disturbed ciliary function of the sinus mucosa are largely responsible for the above fact.

The authors investigated micro-structures in the surface of the sinus mucosa by centering on the morphological changes of the ciliated structure in the samples obtained by a radical operation for odontogenic maxillary sinusitis, and obtained some findings.

Observation methods: The samples for observation were first washed enough with a phsiological saline solution as soon as possible after collection and divided into two, scanning electron microscopic samples and light microcopic ones. The formers were fixed in $2.5 \%$ glutaraldehyde for 6 hours followed by fixation with $\mathrm{O}_{8} \mathrm{O}_{4}$ for further 3 hours, while the latters were fixed in a $10 \%$ neutral formalin solution. Subsequently, for the scanning electron microscope using evaporated with platinum according to the usual method. On the other hand, the light microscopic samples were embedded in paraffin, prepared to thin section, stained with H-E and examined light microscopically.

Results of observation: A pathological change, such as so called infiltrative type, fibrous type or mixed type, were noted in the mucosa of the chronic maxillary sinusitis. Even though the surface appears to be macroscopically smooth, the microstructural surface had a lot of unevenness, and lesions differed depending on areas of the same region. Of the areas, those with relatively slight lesion exhibited images similar to the normal structural surface of sinus mucosa, and the ciliated cells were clearly seen. Non-ciliated cells were noted dispersedly among the ciliated cells. However, in the areas severe lesion inflammatory by-products appeared frequently; the ciliated cells decreased in number; short cilia, disturbance of directinity and erectness of cilia, and some mutual ciliary fusion was noted. In addition to increase of non-ciliated cells and atypical cells were seen.
\end{abstract}

An interpretation was that such morpathological abnormalities in ciliated structure suggest a disturbed ciliary function for the chronic maxillary sinusitis.

Key words: odontogenic maxillary sinusitis, ciliated epithelia, ciliated structure's abnormalities

金沢医科大学㐘科口腔外科学教空

（主任：塩田 覚教授）

Department of Oral Surgery, Kanazawa Medical
University (Chief: Prof. Satoru Shiota)

受付日：昭和60年10月 21 日 


\section{は じめ に}

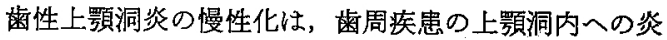
症波及により，上罰洞粘膜に諸変化をきたし，炎症性産 物の排泄低下，停滞などによって助長されるといわれて いる.

これには起炎菌の病原性とその消長はるとより，上䫟 洞粘瞙に括ける多列線毛上皮の病態に基つく，線毛機能 障害によるところも大きいとみなされている1

そこで，著者らは慢性化した雪性上澦洞炎における線 毛上皮の病態を検索するために，本疾患の根本手術より 得た上顎洞粘膜を用いて，線毛構造の形態的变化を中心 に，光顕的ならびに走查電䫓的観察を加えてみた。

\section{観 察 方 法}

観察試料は，歯性上䫇洞炎の臨床診断のもと根本手 術を行った患者 7 名（年齢30〜 40歳，男，女）上り得た 上顎洞粘膜飞加兄て，一部，術後性上矤整胞で根本手術 を行った 3 名の上澦洞粘膜を参考観察試料として用い た.

本試料の採取は，上顎洞根本手術中，上顎洞前壁開警 後，その周辺の洞粘膜の一部をできるだけ損傷を加えな

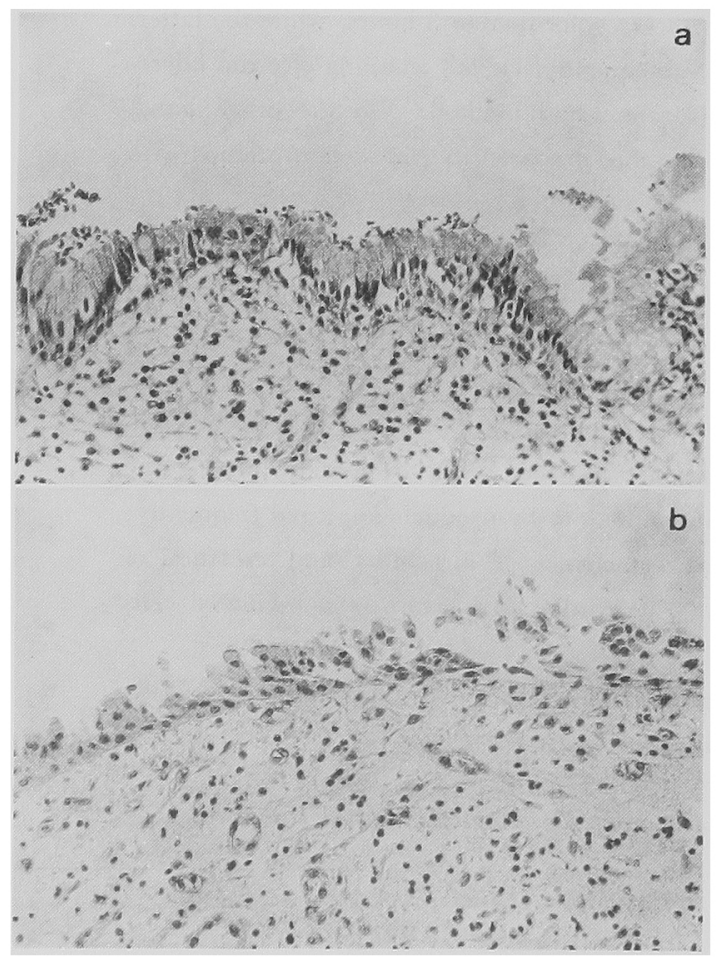

写真 1-a, b 上顎洞粘膜の病理組織像
いようにとり，採取した試料は可及的すみやが生理的 食塩水で洗浄し，ただちに固定処理した．固定は走查電 顕観察用試料として $2.5 \%$ Glutaraldehyde 前固定 (6 時 間）したものと，一部，光顕観察用試料として10\%中性 Formalin 固定を行い，さらに前者の試料は2.0\% $\mathrm{O}_{\mathrm{s}} \mathrm{O}_{4}$ 後固定 ( 3 時間) を加市た。

以後, 通法に従って, 走查電顕観察用固定試料は脱水 を释て，白金スパッタ蒸着を施し，上䋶洞粘膜表面の線 毛構造を中心に鏡検し, 一方, 光頭観察用固定試料は, パラフィン包埋, 薄切切片作製後, H-E 染色のもとで鏡 検した。

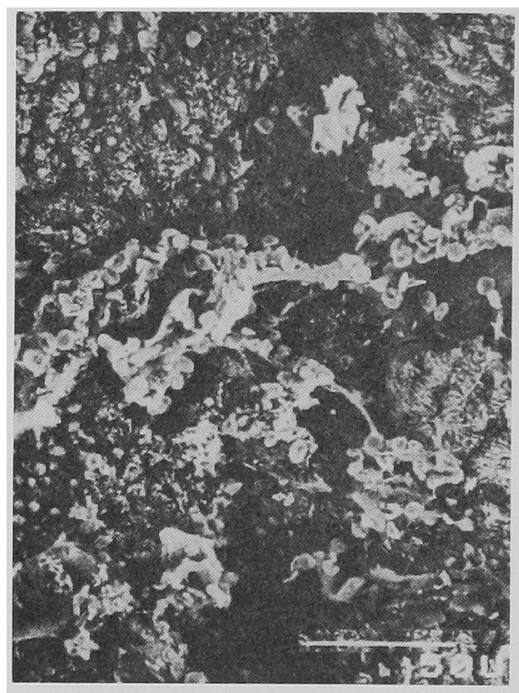

写真 2 多彩な形態的表面構造のみら れる上顎洞粘膜病变

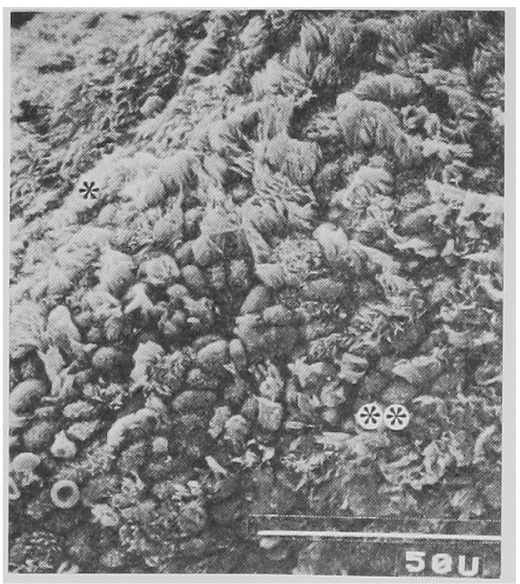

写直 3 比校的豊富な線毛構造のみら れる部位（*）とはとんど無 線毛粨造で占められている部 位 $(* *)$ 


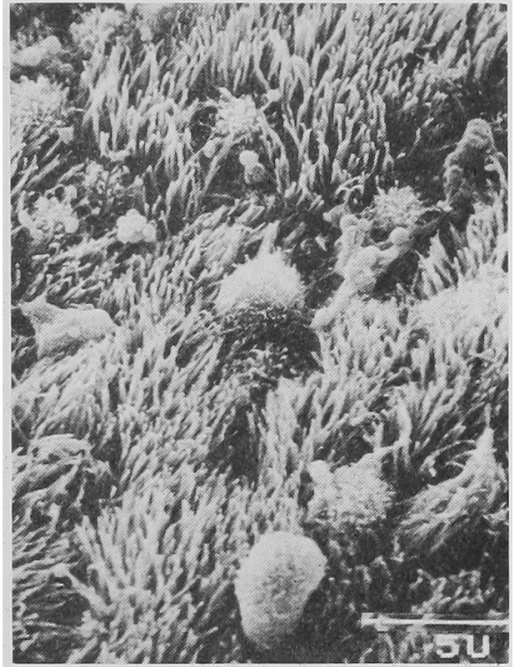

写真 4 比較的䇺富な線毛細胞よりな る上顎洞粘膜表面

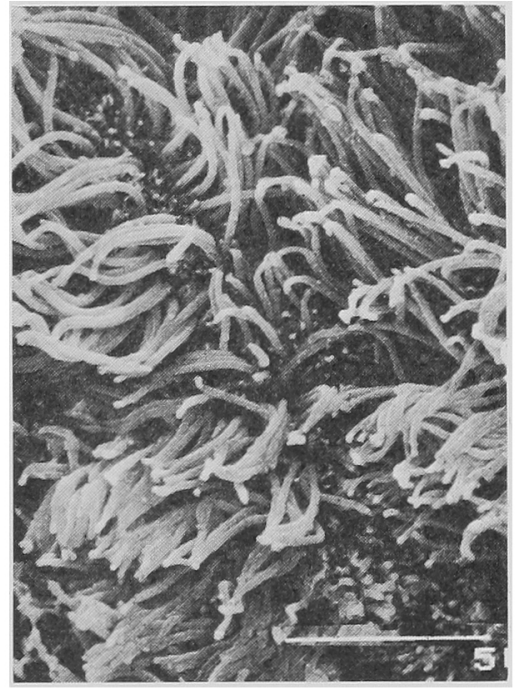

写真 5 相互に協調性をるった波打運 動の様相を呈する線毛

\section{観 察 結 果}

光顉的所見：本観察の対象となった上顎洞粘膜試料の 病理組織像は，多列線毛円柱上皮上りなる粘膜上皮に， ところどころに上皮細胞の変化または上皮構築様式に変 化をきたしている所見を得た（写真 1-a)，一部，上皮 層で多層化または薄層化がみられ，杯細胞の增多，2〜 3 風の立方形または扁平化生す認められた。ささらに，顕 著な病変を伴っているところでは, 変性上皮の䟝離, 脱

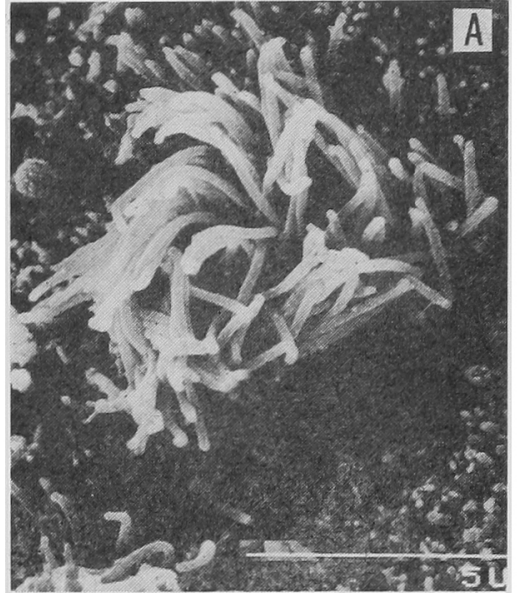

写真 6-A 1 個の楾毛稩胞の自由表。 面より起立している線毛

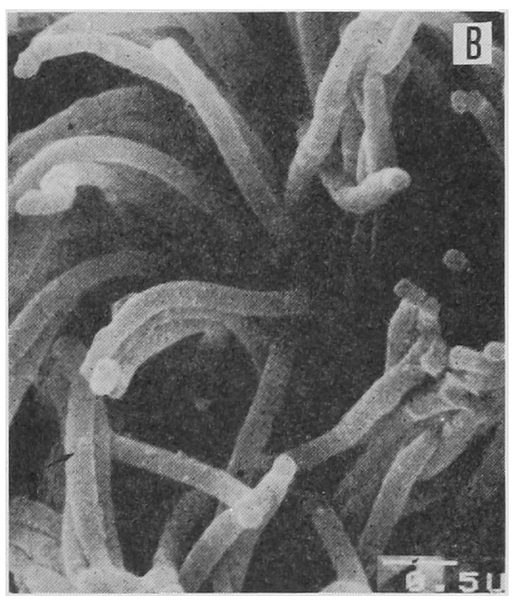

写真 6-B 同一部拡大像

㜊棒型をした線毛とその体部にみられ る做小顆粒状の付加物（矢印）

落るみられた（写真 1-b）。また，上皮下層では，線維 性結合組織中に程度の差がみられるが小円形細胞浸潤が 加わりななかはかなり線維化傾向を伴ったところる認 められた。

走查電顕的所見：慢性炎症を伴った上買洞粘膜表面の 微細構造は，肉眼的に比較的平滑にみえてむ，粗造で凹 凸に富み，多彩な病変像が得られた（写真 2 ). 同一観 察試料中にも，上罘洞粘膜表面が比較的豊富な線毛構造 を有している部位から，ほとんど線毛が欠如し無線毛構 造で占められている部位まで観察され，多彩な棈造所見 を得た（写真 3). 相対的に血球, 細菌類などの炎症性 産物の遊出，停滞が多くみられた。これらの諸変化は， 各部位に和ける病変の強弱を示唆しているものと解され 


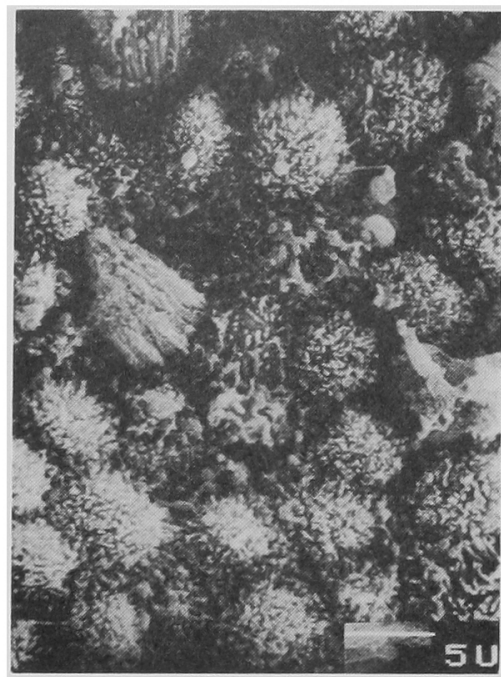

写真 7 多数の微䄉毛を有する無線毛 細胞で大部分を占めている上 額洞粘膜表面

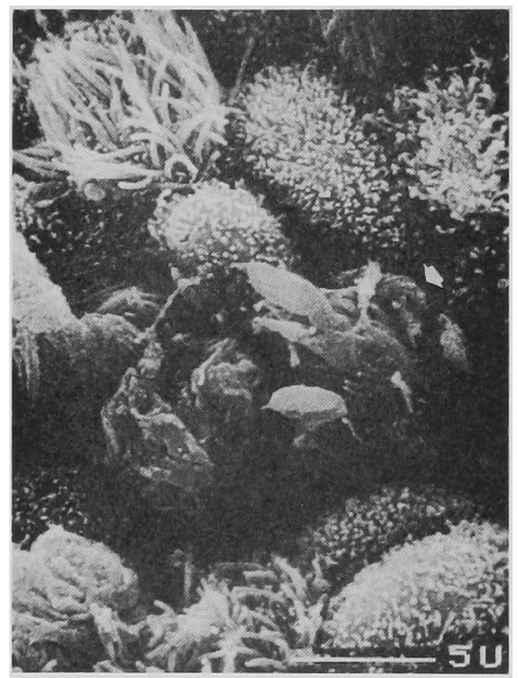

写真 8 微䄉毛に富さ無線毛稩胞間に みられたー見花キャベッ様の 異型勫胞（矢印）

t.

この比較的豊富な線毛が起立し，自由な波打運動様相 のみられる部位では, 個々の線毛は比較的規則正しい起 立性と方向性が保たれ, その間に微䋐毛に富む無線毛細 胞の散在をみた。この部位では血球，細菌類などの炏症 性産物の遊出, 停滞も少なかった (写真4). これらの線 毛は線毛細胞の自由表面から数10本〜百数10本の単位で 起立し，線毛相互が咕調性をもった波打運動を営んでい る所見を得た（写真 5 ）. 線毛の形態は長さが䄪 $6 \mu \mathrm{m}$

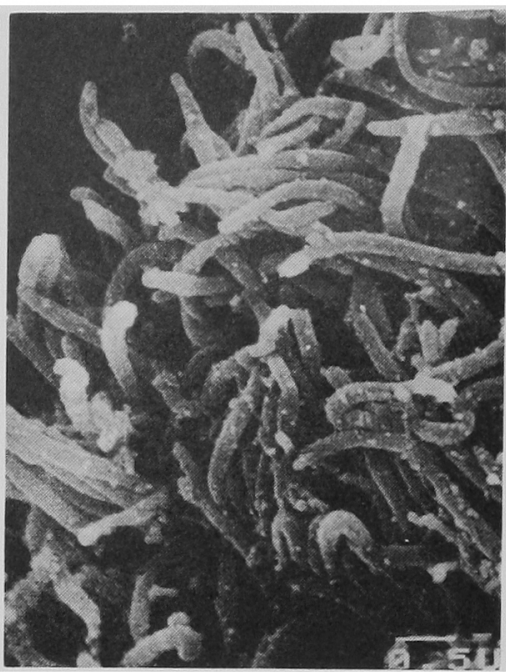

写真 9 屈曲，瞦化执よび相互に絡み 合いをきたしている線毛

で, 太さが $0.2 \mu \mathrm{m}$ 前後の根捧型で,この先端は丸味を 帯び，一見，豆球をとり付けているよらな像を呈してい た．棍捧型をした線毛の体部には，ところどころに微小 顆粒状の付加物 (いわゆる noch) を認めた（写真 6-A, B).このような形態的微細構造よりなる上顎洞粘膜表 面は，本観察試料のなかでは一部分にみられたに過ぎな かった.

上顠洞粘膜表面の大部分では，線毛細胞の減少，線毛 の短小化，これに代って短い媺絨毛を有する無線毛細胞 の増加している部位が多かった（写真 7).さらに，無 線毛細胞の増加に伴って, その間に異型の細胞の出現を 認めた（写真 8 ).

線毛構造の形態的諸变化，これに伴ら線毛機能障害を 示崚する所見は, 炎症性産物の多量に遊出, 停淸してい る部位にみられ, 線毛の屈曲, 膨化または短小化, 線毛 相互の絡み合い，さらに線毛相互の癒着などの変化を認 めた。

線毛の屈曲，膨化は，線毛機能障害を示唆するごく初 期の変化とみなされ，棍捧型をした線毛が，先端部で軽 度に屈曲しているるのから，線毛の体部または基部近く で強く屈曲しているものまでみられた（写真9）。この 線毛の屈曲はある程度可逆性を有し, 元の状態に復する と思われたが，しかし，線毛の屈曲が強く，屈曲部を境 にして膨化をきたしている線毛では，元の状態に復する ことは期待できないよらな所見を得た。このような線毛 の形態的変化に加えて，線毛相互の絡み合いをきたし， 波打運動の協調性の乱れを招来しており，線毛機能障害 を推移している像を呈していた。 ところどころにみられ た線毛の短小化は，十分な線毛機能が期待できないが， この短小化が線毛に受けた外的傷害によるすのかある 


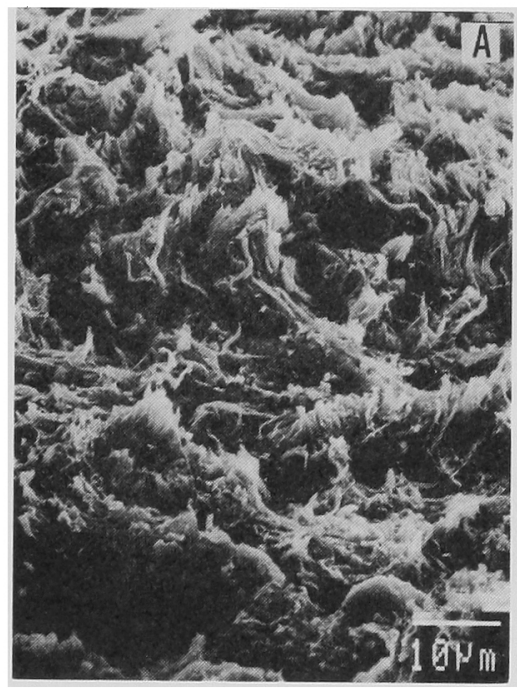

写啹 10-A 顕著な線毛遝動の乱れが みられる上䫑洞粘膜表面

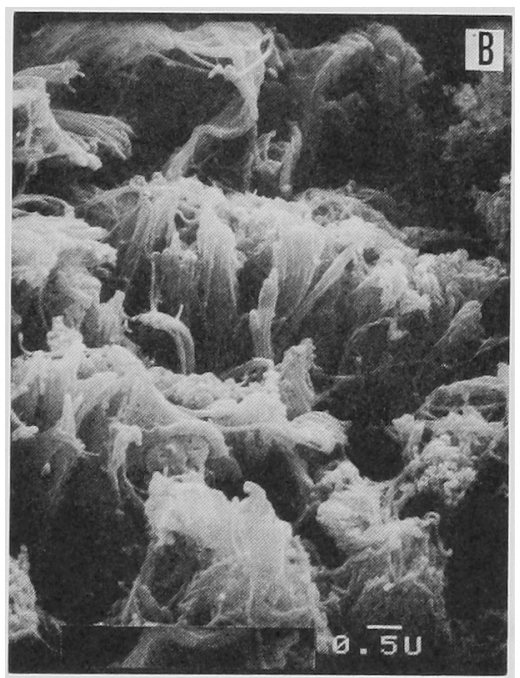

写真 10-B 同一部拡大像 先端部で相互の療着をきたしている楾 毛

いは消失した線毛に代って再生または新生しつつある線 毛であるのかは解読できなかった。

線毛相互にみられる癒着は, 形熊的変化のなかで顕著 な線毛機能障害を示唆する所見とみなされ，この瘑着は 数本の線毛が先端部で瘾着しているすのから，10数本， それ以上の線毛が先端部のみならず体部を含めた瘾着を きたしているすのまで認められた。なかには一束になっ て瘺着された線毛が基部から倒れている像を呈している ものもみられた（写真10-A， B）。これら線毛相互にみ

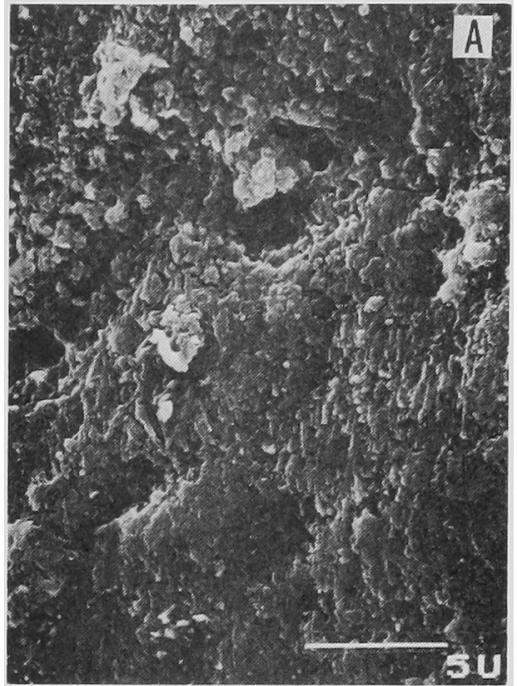

写真 11-A 正常な線毛構造のみられ ない粗造な上顎洞粘膜表 面

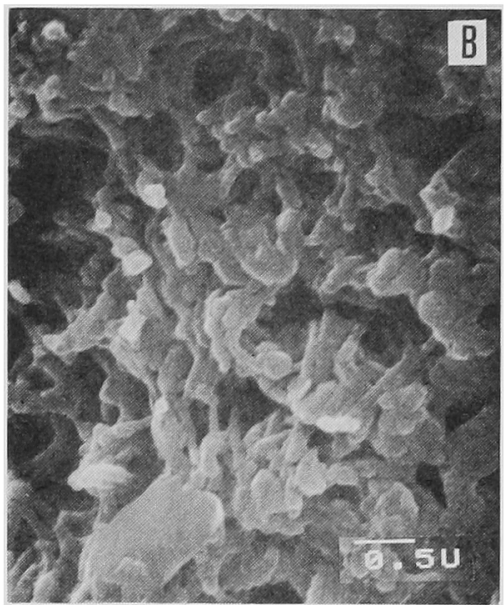

写真 11-B 同一部拡大像

られた癋着は，大部分が解消されるのかる知れないが， もし固定化されると線毛機能の喪失につながるものと思 慮された，さらに，写真11-A，Bにみられるよらな状 態では明らかな線毛機能の亦失を示咬しているものと解 している。

一方，線毛細胞の減少に伴って增多がみられる無線毛 細胞は, 細胞の自由表面には多数の短い㮹䄉毛が起立 し，先端部に大なり小なり炎症性産物の付着物をみた。 この微絾毛の数は細胞によって多いものと比較的少ない すのがみられ，数的差異を認めた（写真 7). また、こ れら無線毛細胞間に，一見，花キャベッ様の異型細胞の 出現子みれた（写真 8 ). 


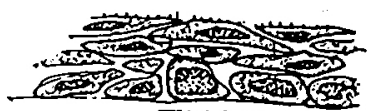

扁平上皮化生

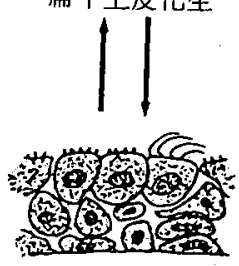

構築の変化

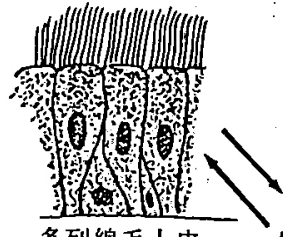

多列線毛上皮
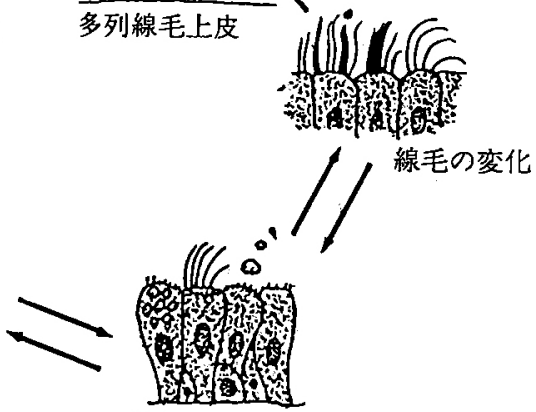

構成細胞の変化

图 1 副鼻腔粘膜の病的変化 高坂ら (1977)

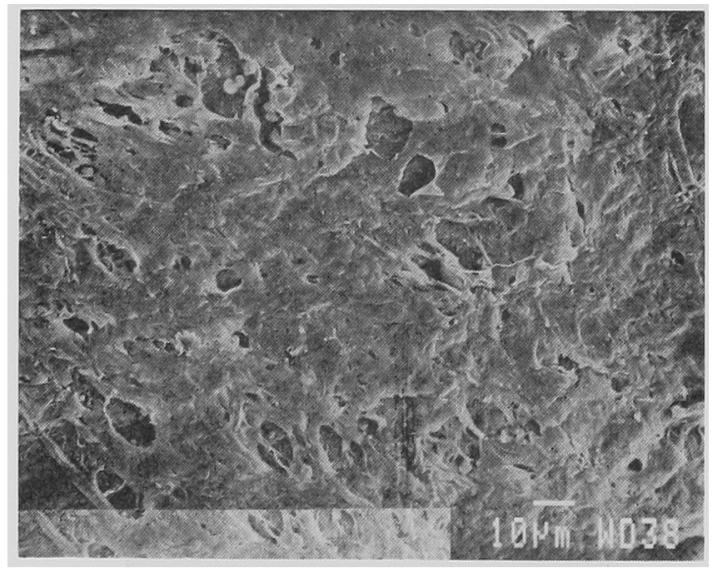

写真 12 上皮の変性㔀離, 脱落したとみなされる 縞模㥞構造をとる上顎洞粘膜表面

なお，本観察試料のなかで，一部上顎洞粘膜表面に線 毛叔よび無線毛細胞がみられず，縞模様構造を呈したと ころがあったが，この表面構造は上皮の変性剝離，脱落 した部位でないかと推察している(写真12).

\section{考察}

一般に上靧洞粘膜における炎症の慢性化による病変 は, 起炎菌の病原性とその消長に上り洞粘膜の線毛上皮 を中心に形態的ならびに組織学的变化をきたし，炎症性 産物の排泄，停滞を助長するといわれている。

この慢性炎症を伴った上䪽洞粘膜の病理組織像は, Mannase (1923) の報告による分類に沿って, 浮腫型;
浸潤型，線維型およびその混合型に大別されており，各 型で程度の差がみられるが，上皮徉では，線毛上皮細胞 の減少無線毛上皮細胞执よび杯細胞の増多，ひいては扁 平上皮化生,さらに変性上皮の㔀㕍, 脱落を, また，上 皮下層では大なり小なり炎症性細胞浸潤を伴らことが指 摘されている1,4〜7)

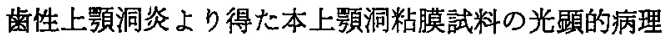
組織像では，多列線毛円柱上皮よりなる洞粘膜上皮は， 上皮構成細胞の変化, さらには上皮盽築様式の変化をみ た．粘膜上皮層では，多層化または薄㬝化がみられ，一 部，杯細胞の増多， $2 \sim 3$ 層の立方形または扁平化生， さらに，変性上皮の剝離，眖落をきたしているところも あった。 上皮下層では線維性結合組織中に程度の差がみ られたが，小円形細胞浸潤を伴っていた.これら病理組 織型は，浸潤型または浸潤型と線維型の混合型を示し、 炎症の繰り返しによる慢性刺激を伴った病変を示唆して いた.

なお，この病理組織像は，上頻洞前壁開籢周辺より得 た試料であるので，性上額洞炎の病変全体像とは言い 難く，上買洞内の部位により差異がみられることも否定 できないと考えている。

正常な上額洞粘膜表面の形態的微細構造は，表面の大 部分が規則正しい起立性と方向性を有した線毛で和おかわ れ、これらの線毛が相互に協調性をむって波打運動を営 み, 重要な機能的役割を果たしているといわれている8) 慢性上買洞炎では，この上買洞内に分布する線毛構造に 諸変化をきたし, 線毛機能障害が注目されている 本篗察試料における炎症の慢性化した上䫑洞粘膜表面 は，肉眼的に一見平滑にみえても，走査電顕的観察で は，実に粗造で凹凸に富み，多彩な像を呈していた（写 
真 2).

この表面は，比較的豊富な線毛でおおわれている部位 から，ほとんど線毛が欠如し無線毛構造を示す部位まで 認められたが (写真了), 全体的にみて線毛細胞の減少 または線毛自体の形態的变化がみられ, 線毛細胞の減少 した部位では多数の微䋐毛を有する無線毛細胞の增多を 認めた。両細胞の增減は相関性を有しているよらな所見 を得た。また，表面には血球，細菌類などの炎症性産物 の遊出, 停滞が多かった.

比較的豊富な線毛細胞よりなる上顎洞粘膜表面から得 た正常に近い形態的構造を示す線毛は（写真 6-A， B ), 個々の線毛細胞自由表面より数10本〜百数 10 本の線毛が 起立し, この線毛は太さが約径 $0.2 \mu \mathrm{m}$, 長さが $6 \mu \mathrm{m}$ 前 後の棍捧型で, 先端は丸味を帯び, 体部にところどころ に顆粒状添加物（noch）をみた。これら線毛相互が一定 の協調性を持った波打線毛運動を営んでいる所見を得 た. 正常な線毛紐胞より起立している線毛は, 数的に報 告者によって多少差異がみられるが9 11)，1個の線毛細 胞自由表面より200〜250本の線毛が報告されている。 た, 形態的には線毛の太さが約径 $0.2 \mu \mathrm{m}$, 長さが 5 $10 \mu \mathrm{m}$ とみなされている(10,11)。ちなみに, この線毛運動 は実に活発で, 上気道の線毛では 1 分間700 1, 000回に も及ぶ波打運動が行われているともいわれている9 のような正常に近い線毛構造がみられた部位は, 本観察 試料では一部分に過ぎなかった。

線毛を有する上靧洞粘膜表面といえども，線毛自体に 形態的变化を伴っているものが多かった。すななわ，線 毛の屈曲, 膨化または短小化, さらに, 線毛相互の絡み 合い, 癒着などの变化をみた。

線毛の屈曲, 膨化は, 線毛機能障害を誘発する初期の 形態的構造变化とみなされる。この屈曲, 膨化が線毛相 互の絡み合いを伴い（写真 9), 線毛の波打運動の協調 性喪失を招来し, 線毛機能障害に発展し, ひいては上䫇 洞内に打ける炎症性産物の排泄低下をきたするのと推察 された. 線毛相互の嘴着は, 種々の程度の癒着がみられ たが，中等度の形態的構造変化を示唆しているとみなさ れた. 数本の線毛が先端部で癒着しているものから，10 数本, それ以上の線毛が痛着, 転倒のみられたものまで あったが (写真10-A, B), 多数の線毛の癒着, 転倒し た状態では, 線毛機能障害の著しい増強と思われた。 こ れら線毛相互の癒着には, 炎症性産物を含めた洞内の粘 液性物質の性状が，瘉着の要因に大きく関与しているも のと考えられる.

高坂ら (1977)1) Ohashi and Nakai $(1983)^{2)} \bigsqcup^{3 \sim 7,12)}$ は, 慢性鼻副鼠腔炎に打ける線毛上皮の諸変化に関して 検索を加兄ており，高坂ら (1977) ${ }^{11}$ によれば図 1 にみら れる副番腔粘膜の病的变化を指摘している.すなわち, 軽度な病変では細胞表面に扣ける線毛の変化つまり線毛 相互の融合などがみられ, 高度な病変になると, 本観察
試料でところどころにみられた線毛細胞の減少, 無線毛 細胞の增多といった細胞構成に変化をきたすといってい る. さらに, 洞閉塞状態, 反復感染などの負荷が加わる と上皮層の構築変化をきたし,ひいては上皮の扁平化生, 変性細胞の剥離, 脱落がみられると述べている.

なお，本観察に打いて，一部，参考観察試料として術 後性上罘露胞を含めて検索したが, 線毛構造の形態的諸 変化は，雪性上顎洞炎にみられた諸構造变化と類似点が 多かった ${ }^{13 \sim 18)}$.

\section{まと め}

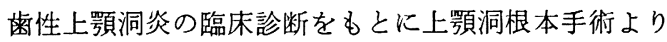
得た洞粘膜試料を用いて, 線毛構造の形態的变化を中心 に走查電䫓的観察した.

\section{結 果}

1）上䫕洞粘膜表面の形態的微細構造は, 実に粗造で 凹凸に富み, 多彩な像を得た。

2 ）洞粘膜表面は, 豊富な線毛を有する線毛細胞の減 少, 比較的短い微䋐毛よりなる無線毛細胞の増多を認め た.

3）これらの表面には, 血球, 細菌類などの炎症性産 物の遊出, 付着が多かった。

4 ）炎症性産物の排泄に重要な役割を果す線毛の形態 的構造変化として, 線毛の屈曲, 膨化, 線毛の短小化, 線毛相互の絡み合い, さらに, 線毛相互の癒着などがみ られた。

5 ) 線毛相互の癒着は, 線毛波打運動機能の著しい减 退を招来し，炎症性産物の排泄低下が示唆された。

\section{引用 文 献}

1）高圾知節, 小野寺 亮, 他: 鼻副鼻腔粘膜病態 の電子顕微鏡的研究。耳鼻 26: 623-645 1977.

2) Ohashi, Y. and Nakai, Y.: Functional and morphological pathology of chronic sinusitis mucous membrane. Acta Otolaryngol Supple 379: 11-48 1983.

3) Herzon, F.S.: Nasal ciliary structural pathology. Laryngoscope 93: 63-67 1983.

4) 岡田博旮：慢性上䫇洞炎粘膜の病理組織学的研 究。日耳忽 64：1240-1252 1961 。

5）八尾和雄：慢性副息腔炎に扰汁る上䫇洞粘膜の 病理組織学的研究。日耳強 86：988-1004 1983.

6) 能己敏郎：正常並びに病的状態に打けると卜副 鼻腔粘膜の超证形態的研究。 日耳鼻 72: 122112311969.

7) 兵 行和：慢性上顎洞炎に扣ける粘液上皮細胞 の電子顕微鏡的钼察. 耳忽臨床 71(增 2)：7127321978.

8) Satir, P.: How cilia move. The hairlike or- 
ganelles that propel swimming cells or move liquids over fixed cells are composed of sheaves of microtubules. The cilia beat when the microtubules, powered by ATP, slide past one another. Sci Am 231: 45-52 1974.

9) 切替一郎: 新耳鼻咽喉科学. 南山堂, 東京, 1967，185-186頁.

10) Kelley, D.E., Wood, R.L., et al.: Bailey's Textbook of Microscopic Anatomy. 18 th Ed, Williams \& Wilkins, Baltimore/London, 1984 p 135-138.

11) 北村 武編：耳鼻咽喉科学. 文光堂, 東京, 1985 31-33，98-99頁.

12) 関山三郎, 藤田進, 他：口腔外科領域に打け る走查電顕の利用について，その2. 上顎洞粘 膜 (抄). 日外誌 21：372 1975 .

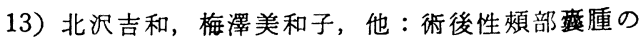
走査型電䡩像扰よび透過型電顕像について。耳 展 17: 83-88 1974. 補1.

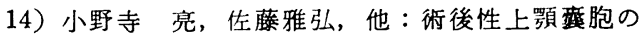
電子顕微鏡的研究. 日耳鼻 81：918-925 1978.

15）谷口強, 坂倉康夫, 他: 走査電顕による柇後

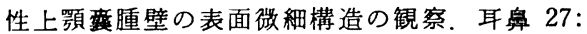
333-340 1981. 補2.

16）藤田進, 松本断, 他: 犹後性上顎罴胞の走 査電顕による钼察。日口外誌 23：943 1979.

17）石川武憲, 翁 志嵩, 他: 術後性煩部雚胞壁由 来線毛稩胞の走査電㪟について(抄). 日口外誌 29: 6231980 .

18）岡田とし江，佐藤淳一，他：術後性上顎蒜胞の 走査電顕による観察 (抄). 日口外誌 30：2014 1984. 